\section{Yield, Labor, and Fruit and Juice Quality Characteristics of Machine and Hand-harvested 'Brown Snout' Specialty Cider Apple}

\author{
Carol A. Miles ${ }^{1}$ and Jaqueline King
}

ADDITIONAL INDEX wORDs. fruit storage, hard cider, harvest labor, Malus $\times$ domestica, mechanical fruit harvest, over-the-row harvester

SUMMARY. In this 2-year study of 'Brown Snout' specialty cider apple

(Malus $\times$ domestica) grafted onto Malling 27 (M.27) and East Malling/Long Ashton 9, we compared weight of total harvested fruit, labor hours for harvest, tree and fruit damage, and fruit and juice quality characteristics for machine and hand harvest. Machine harvest was with an over-the-row small fruit harvester. There were no significant differences due to rootstock; however, there were differences between years for most measurements. Weight of harvested fruit did not differ because of harvest method; however, harvest efficiency was $68 \%$ to $72 \%$ for machine pick and $\mathbf{8 5 \%}$ to $89 \%$ for machine pick + clean-up weight (fruit left on trees and fruit knocked to the ground during harvest) as compared with hand harvest. On average for the 2 years, hand harvest required 23 labor-hours per acre at a total cost of $\$ 417$, while machine harvest required 5 labor-hours per acre at a cost of $\$ 93$. There were no differences due to harvest method on damage to spurs (four to eight spurs damaged per tree) or limbs (0.5-0.8 limbs damaged per tree). Although there were also no differences due to harvest method on fruit bruising ( $100 \%$ for both harvest methods in this study), $10 \%$ of fruit were sliced and $4 \%$ of fruit were cut in half inadvertently with machine harvest, and none were sliced or cut with hand harvest. Harvest method had no effect on fruit quality characteristics, specifically, soluble solids concentration (SSC), $\mathrm{pH}$, specific gravity, titratable acidity (malic acid equivalents), or percent total tannin, when fruit was pressed immediately after harvest or stored for 2,3 , or 4 weeks before pressing. Juice quality characteristics were affected by storage, and SSC increased $11 \%$ in 2011 (3 weeks storage), and $12 \%$ and $18 \%$ in 2012 ( 2 and 4 weeks storage, respectively). Similarly, specific gravity increased both years after storage, $1 \%$ in 2011 , and $1 \%$ and $2 \%$ in 2012 (a $1 \%$ increase in juice specific gravity corresponds to a potential $1.3 \%$ increase in alcohol by volume after fermentation for cider). Both years, juice $\mathrm{pH}$ tended to decline when fruit was stored $(0.01 \mathrm{pH}$ units in $2011,0.06-0.12 \mathrm{pH}$ units in 2012). Overall, cider apple harvest with an over-the-row small fruit machine harvester used four times less labor than hand harvest, yield reached $87 \%$ that of hand harvest (when clean-up yield was included), and juice quality characteristics were not negatively affected. These results suggest that machine harvest may be suitable for cider apples if equipment is available and affordable.

$\mathrm{C}$ ider, or "hard cider" as it is typically known in the United States, is fermented apple juice with $0.5 \%$ to $7 \%$ alcohol by volume (U.S. Department of Treasury, 2001). Nonfermented, unfiltered apple juice is referred to as "fresh cider" or "sweet cider," and the term "apple juice"

Department of Horticulture, Washington State University, 16650 State Route 536, Mount Vernon, WA 98273

The funding support was provided by the Washington State Department of Agriculture and Washington State University CSANR BIOAg Program.

Technical support for this project provided by Jonathan Roozen, Kyle Craig, and Karen Hasenoerhl is gratefully acknowledged. Recognition is also given to Gary Moulton who conceived and initiated this study by establishing the specialty cider orchard for mechanical harvest in 2002 .

${ }^{1}$ Corresponding author. E-mail: milesc@wsu.edu. indicates the liquid from pressed apples has been filtered to remove solids (Khanizadeh et al., 2000; Trowbridge, 1917). Hereafter, the term "juice" will be used to refer to nonfermented apple juice, and the term "cider" will be used to describe the fermented beverage. Until the late 1800s, cider was the most popular alcoholic beverage made and consumed in the United States; however, by the early 1900s, cider had essentially disappeared from U.S. markets (Proulx and Nichols, 1997). The rapid decline of cider was due to a combination of factors, primarily a high influx of German and eastern European immigrants who preferred beer, and many farmers who were sympathetic to the Temperance Movement cut down their apple trees (Watson, 1999).

Cider is currently seeing a revival in the United States and although it only accounts for $1 \%$ of the alcoholic beverage market, it is the fastest growing alcohol market segment, with $54 \%$ increase in production each year from 2007 to 2012 (Morton, 2013; U.S. Department of Treasury, 2013). In 2007, 0.8 million gallons of cider were produced in the United States; this increased nearly 7 -fold to 5.2 million gallons in 2012. The volume of cider produced in Washington State grew by over 3 -fold between 2007 and 2012 (from 44,387 to $173,288 \mathrm{gal})$, a $37 \%$ growth rate per year, and accounted for $6 \%$ of the total U.S. cider production in 2007 and 3\% in 2012. The number of cideries in Washington increased 7 -fold in this time period, from four cideries in 2008 to 29 in 2014 (Brown, 2014; Northwest Cider Association, 2014).

To meet the new demand for cider in the United States, there is increasing demand for apples to make quality cider. Quality cider is traditionally made from apple varieties that are classified as bittersweet (tannins > $0.2 \%$, acids $<0.45 \%)$ or bittersharp (tannins $>0.2 \%$, acids $>0.45 \%$ ) (Barker, 1903; Barker and Burroughs, 1953). Historically, growers both in Europe and the United States selected cider apple varieties for these traits (Alwood, 1903; Barker, 1911; Barker and Burroughs, 1953; Buell, 1869; Trowbridge, 1917). Most

\begin{tabular}{llll}
\hline $\begin{array}{l}\text { Units } \\
\text { To convert U.S. to SI, } \\
\text { multiply by }\end{array}$ & U.S. unit & SI unit & $\begin{array}{l}\text { To convert SI to U.S., } \\
\text { multiply by }\end{array}$ \\
\hline 0.4047 & acre $(\mathrm{s})$ & $\mathrm{ha}$ & 2.4711 \\
29.5735 & $\mathrm{fl} \mathrm{oz}$ & $\mathrm{mL}$ & 0.0338 \\
0.3048 & $\mathrm{ft}$ & $\mathrm{m}$ & 3.2808 \\
3.7854 & $\mathrm{gal}$ & $\mathrm{L}$ & 0.2642 \\
0.4536 & $\mathrm{lb}$ & $\mathrm{kg}$ & 2.2046 \\
1.1209 & $\mathrm{lb} / \mathrm{acre}$ & $\mathrm{kg} \cdot \mathrm{ha}^{-1}$ & 0.8922 \\
28.3495 & $\mathrm{oz}$ & $\mathrm{g}$ & 0.0353 \\
6.8948 & $\mathrm{psi}$ & $\mathrm{kPa}$ & 0.1450 \\
$\left({ }^{\circ} \mathrm{F}-32\right) \div 1.8$ & ${ }^{\circ} \mathrm{F}$ & ${ }^{\circ} \mathrm{C}$ & $\left({ }^{\circ} \mathrm{C} \times 1.8\right)+32$
\end{tabular}


finished ciders usually contain several apple varieties that are blended to attain a final product that has desirable levels of acidity, polyphenols, and the alcohol that results from fermentation of naturally occurring sugar (Khanizadeh et al., 2000; Lea, 2008; Merwin et al., 2008; Pollard, 1953). Most cider makers in the United States use cull fruit from fresh/dessert apple orchards to form the cider base as this fruit tends to be more readily available and relatively inexpensive; they then augment this with juice of specialty cider varieties if available (Merwin et al., 2008; Moulton et al., 2010). In an informal survey in 2012 and 2013, five prominent cider makers in Washington and Oregon indicated they paid $\$ 0.10$ to $\$ 0.25$ per pound for cull fruit of fresh/dessert apples and $\$ 0.15$ to $\$ 0.75$ per pound for specialty cider apple varieties (S. Galinato, personal communication).

To meet market demand for specialty cider apples, growers in the United States require cost-effective orchard practices to be cost competitive with other agricultural production systems. In the United Kingdom, which has a long history of cider production and is the world's largest producer of cider as well as the largest market, fruit is almost exclusively harvested by machine (National Association of Cider Makers, 2010). Specialty cider apple growers use tractor-mounted tree shakers to knock fruit to the ground, then tractormounted air blowers and mechanical brushes are used to sweep up the fruit from the orchard floor (Fitzgerald et al., 2013; Lea, 2008). These methods were developed for traditional orchards with large, widely spaced trees, and are still used today in the United Kingdom as cider production is focused in regions where trees on dwarfing rootstock are not sufficiently productive (K. Evans, personal communication).

Washington State is the largest producer of apples in the United States, and with around 156,000 acres of apples, accounted for $48 \%$ of the U.S. apple supply in 2011 [U.S. Department of Agriculture (USDA), 2014]. Modern dessert apple orchards include dwarfing rootstock and trellis systems with 1200 to 1800 trees/acre (Fallahi, 2012; Lehnert, 2010; Marshall and Andrews
1994; Schotzko and Granatstein, 2005; Washington State University Extension, 2013). New specialty cider apple orchards in Washington include semidwarfing rootstocks and $\approx 700$ trees/acre (Galinato et al., 2014). Cider fruit is harvested by hand, and hand harvest accounts for $46 \%$ of the total annual variable costs when the orchard is in full production (Galinato et al., 2014). Fruit size of most cider apple varieties is smaller than standard dessert apple varieties, and it can take up to four times longer to pick one bin of cider apples than a bin of dessert apples (A. Zimmerman, personal communication). Cost of harvest labor is a significant consideration especially in areas without a large agricultural labor force, where labor costs are high, or both.

Washington is also the leading raspberry (Rubus idaeus) production region in the United States, and with 9800 acres and 62.7 million pounds of production, accounted for $89 \%$ of the U.S. acreage and $65 \%$ of production in 2012 (USDA, 2014). Raspberries destined for the processing market are harvested with machines that are driven over the row. These over-the-row small fruit harvesters include vertically oriented spikeddrum shakers that rotate freely and cause fruit to drop (Funt et al., 1998). Fruit fall onto a catch plate, roll into cups, and are conveyed vertically to a cleaning and sorting belt at the top of the harvester. Sorted fruit are collected in field containers, which are then removed from the machine by hand at the end of the row by lowering the fruit collection platform. Over-the-row harvesters typically used for raspberry harvest in northwest Washington may be suitable for harvesting trellised cider apples. Small-scale cider apple growers generally press fruit within a few days to 1 month after harvest; therefore, fruit damage that occurs from machine harvest may negatively affect juice quality characteristics. In this 2-year study of 'Brown Snout' bittersweet specialty cider apple grafted onto M.27 and East Malling/Long Ashton 9 (EMLA9) rootstocks, we compared the total weight of harvested fruit, labor hours for harvest, tree and fruit damage, and fruit and juice quality for traditional hand harvest and mechanical harvest using an over-the-row small fruit harvester.

\section{Materials and methods}

OrChard PLANTING. The orchard for this study was established in 2002 at Washington State University Northwestern Washington Research and Extension Center at Mount Vernon. The orchard site has soil type Skagit silt loam, classified as a fine-silty, mixed, nonacid, mesic Typic Fluvaquent recently formed of alluvium and volcanic ash (USDA, 2013). Specialty cider apple 'Brown Snout' grafted on two rootstocks, M.27 and EMLA9, was planted at 16 - $\mathrm{ft}$ between-row and 4 - $\mathrm{ft}$ in-row spacing. Orchard planting density was 680 trees/acre. Between-row spacing was wider than commonly used in commercial orchards to accommodate potential unknown needs for mechanical harvest. Trees were trained to a three-wire trellis system with post height of $6.5 \mathrm{ft}$. The lowest wire was $2 \mathrm{ft}$ above the soil surface to accommodate the catch plate of the mechanical harvester. In 2011 , tree limbs were attached tightly to the trellis wires and were pruned to maintain a narrow canopy, whereas in 2012, limb attachment to the trellis wires was loosened and pruning was adjusted to widen the canopy so that the harvester shaker bars could more readily shake the fruit off the trees.

The experimental design was a randomized complete block split plot. The main plot was rootstock (M.27 and EMLA9) and the subplot was harvest method (hand and machine). There were two replicates of the main plot treatment and nine trees per subplot. The study was carried out in 2011 and 2012.

Harvest, yield, AND LABOr. Fruit was harvested when fully ripe on 25 Oct. 2011 and 17 Oct. 2012. Fruit ripeness was measured with the starch conversion test (Blanpied and Silsby, 1992; Lau, 1988). In each row, three fruit were sampled once weekly beginning 3 weeks before expected harvest. When at least $90 \%$ of the cross section of every sampled fruit was clear of starch (8.5 stage on the Ontario chart), the fruit was considered to be fully ripe and the orchard was harvested (Chu and Wilson, 2000; Lau, 1988). Immediately before harvest each year, preharvest groundfalls were removed from all plots.

Both years, hand harvest was done by four unskilled agricultural workers 
who were not specialized in apple picking. Machine harvest was done with an over-the-row small fruit harvester (model OR0012; Littau Harvester, Lyndon, WA) operated by an experienced harvester driver. In addition, two unskilled agricultural workers moved fruit from the machine harvest belt into totes on top of the harvester (Fig. 1). Hand-harvest plots were picked first, and then respective plots were picked with the machine harvester.

Fruit yield was measured as weight (pounds) of fruit harvested from each plot. For hand-harvest plots, all fruit were picked from trees and any fruit that fell to the ground during picking were also picked up and included in the total yield, following common grower practices as groundfalls can be used to make cider. For machine harvest plots, fruit was harvested with the over-the-row harvester, and the fruit weight was recorded. All fruit remaining on trees following machine harvest as well as fruit that fell to the ground during harvest were picked and weighed together, and were considered to be clean-up fruit weight. Harvest efficiency was calculated as the weight of fruit that was picked by the machine as compared with hand harvest, and for fruit weight of machine pick + clean-up weight (fruit left on trees and fruit knocked to the ground during harvest).

The number of labor-hours required to pick each plot was recorded, and the cost of labor per acre was calculated based on wage rates paid by
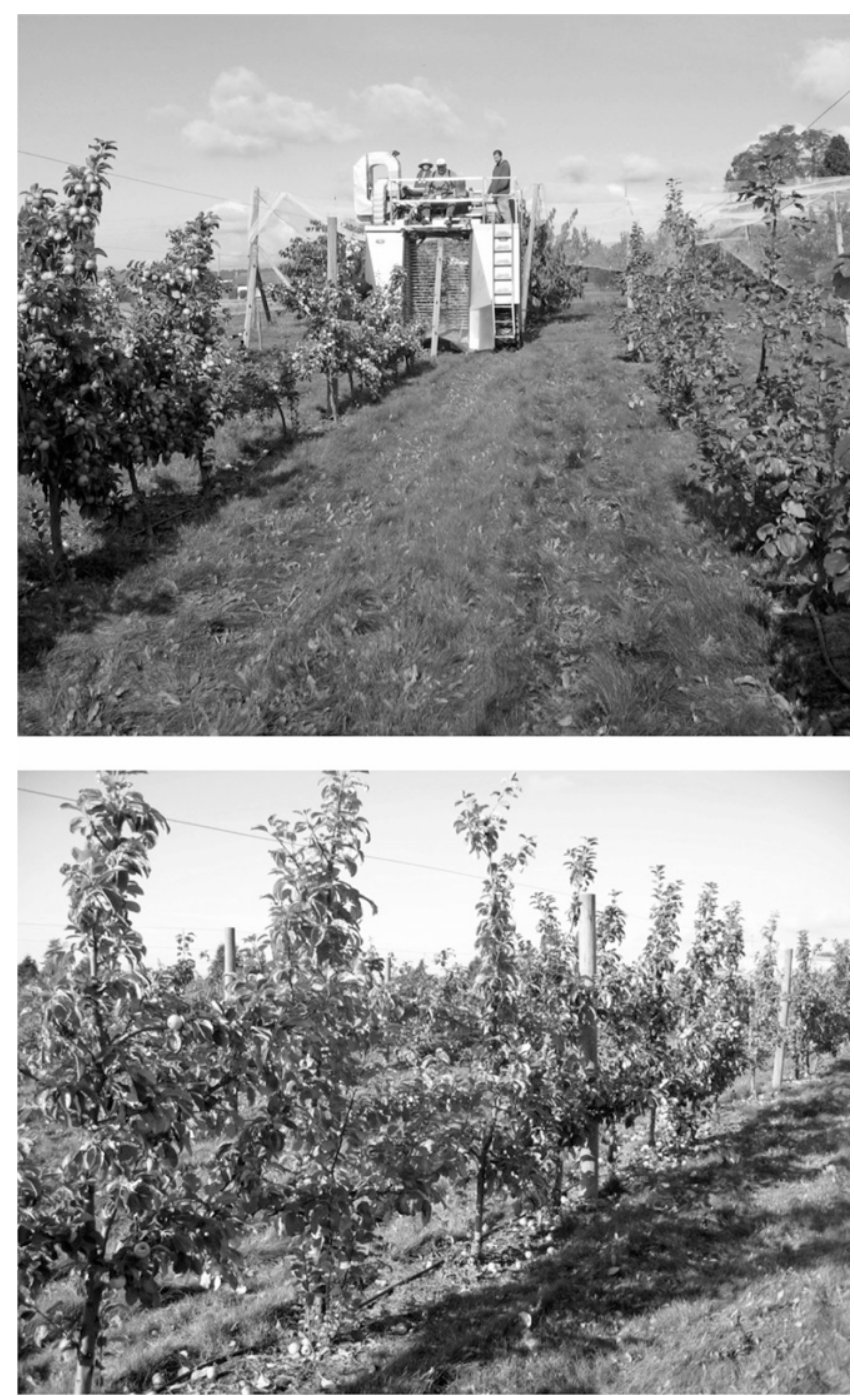

Fig. 1. Over-the-row small fruit machine harvester (model OR0012; Littau Harvester, Lyndon, WA) harvesting 'Brown Snout' specialty cider apples (top); trees just after machine harvest (bottom).

local growers for similar work. For hand harvest, all workers were considered to be paid the same wage, $\$ 18 / \mathrm{h}$, which included applicable taxes and benefits. For machine harvest, the value of labor for handling fruit was considered equivalent to the value of labor for hand harvest; however, the driver was valued at $\$ 22 / \mathrm{h}$, which also included applicable taxes and benefits. Time to drive the harvester to the orchard and make adjustments for apple harvest was not included.

Tree Damage, AND Fruit AND JUICE QUALITY CHARACTERISTICS. Each year immediately after harvest, the number of damaged spurs and limbs were counted for two trees per plot. Also, immediately after harvest each year, bushel boxes of fruit were randomly selected from each plot to assess fresh and stored fruit and juice quality characteristics. Both years, one box of fruit per plot was assessed immediately after harvest. For stored fruit, one box per plot was assessed after 3 weeks of storage in 2011, while in 2012 , one box per plot was assessed after 2 weeks of storage and one box per plot was assessed after 4 weeks of storage. Fruit were not sorted after harvest (sliced and cut fruit were not removed), following common grower practices, and fruit were stored at $32{ }^{\circ} \mathrm{F}$ both years in the same cold-storage facility. Before pressing, 100 fruit were randomly selected from each box and the numbers of bruised and cut fruit (sliced and cut in half) were recorded.

Each box of fruit was milled and pressed in a basket cider press (Standard Large; Correll Cider Presses, Veneta, OR); after each sample, the basket cider press was cleaned with a water hose with a high-pressure attachment (line pressure $42 \mathrm{psi}$ ). A $500-\mathrm{mL}$ sample was collected from the juice of each plot, placed in a plastic bottle, and frozen $\left(5^{\circ} \mathrm{F}\right)$. Each year, when all samples had been pressed, juice samples were thawed to room temperature $\left(74{ }^{\circ} \mathrm{F}\right)$ and assayed for SSC, $\mathrm{pH}$, specific gravity, titratable acidity, and tannins. Juice analysis was carried out in the same laboratory both years under controlled temperature, thus there was little fluctuation in temperature from year to year.

Soluble solids concentration (percent) was measured by placing two to 
three drops of the juice sample onto a digital refractometer that was equipped with automatic temperature compensation (Palm Abbe model \#PA201; MISCO, Cleveland, $\mathrm{OH}$ ). Juice $\mathrm{pH}$ was measured for each sample using a digital $\mathrm{pH}$ meter (Orion 3 Star; Thermo Scientific, Pittsburgh, PA). Specific gravity of each sample was measured with a hydrometer [specific gravity range 1.000-1.070 (Bellwether; VeeGee Scientific, Kirkland, WA)]. Titratable acidity (expressed as malic acid equivalents) was measured for each sample by combining $25 \mathrm{~mL}$ juice and $100 \mathrm{~mL}$ distilled water in a $250-\mathrm{mL}$ beaker, stirring with a magnetic stir bar, and titrating with $0.2 \mathrm{M}$ sodium hydroxide $(\mathrm{NaOH})$ to a $\mathrm{pH}$ reading of 8.1 (Gallander et al., 1991). The volume (milliliters) of sodium hydroxide added was recorded and titratable acidity was calculated using the equation: titratable acidity (malic acid equivalents) $=$ milliliters $\mathrm{NaOH} \times$ 0.536

Percent tannin (expressed as tannic acid equivalents) was measured using the Lowenthal permanganate titration method (Burroughs and Whiting, 1960; Lea, 2008; Lowenthal, 1877). For each juice sample, $1 \mathrm{~mL}$ juice was added to $150 \mathrm{~mL}$ distilled water, then $5 \mathrm{~mL}$ indigo carmine solution [ $\mathrm{lg}$ indigo carmine, $1 \mathrm{~L}$ distilled water, and $50 \mathrm{~mL}$ concentrated sulfuric acid $\left.\left(\mathrm{H}_{2} \mathrm{SO}_{4}\right)\right]$ was added. The mixture was titrated with a solution of 0.005 $\mathrm{M}$ potassium permanganate $\left(\mathrm{KMnO}_{4}\right)$ until yellow color was observed, and was comparable in color to the indicator blank. The indicator blank consisted of $5 \mathrm{~mL}$ indigo carmine solution mixed with $150 \mathrm{~mL}$ distilled water, and titrated with potassium permanganate until yellow color was observed. The percent tannins for each sample was calculated using the equation: total tan$\operatorname{nin}($ percent $)=(\mathrm{X}-\mathrm{Y}) / 10$, where "X" is the amount of potassium permanganate added to the sample, and " $Y$ " is the amount of potassium permanganate added to the indicator blank.

Statistical analysis. All data were subjected to analysis of variance using Oneway analysis in JMP (version 8.0.1 for Windows; SAS Institute, Cary, NC). Least squares fit test was performed to verify that there was no interaction between rootstock and treatment method for any of the parameters that were measured. Homogeneity of variance was assessed in all cases using Levene's test in JMP. Treatment means were compared using Tukey-Kramer honest significant difference test at the $5 \%$ level.

\section{Results}

There were significant $(P \leq 0.05)$ differences between years for most of the parameters measured; however, there were no significant differences due to rootstock or interactions between year and rootstock for any of the parameters measured (Table 1 ). There were no interactions between year and harvest method for any of the parameters measured (data not shown). Thus, data for each parameter were pooled for rootstock each year.

Table 1. Results from Oneway analysis of variance (JMP version 8.0.1 for Windows; SAS Institute, Cary, NC) of the main factors "year" and "rootstock," and their interaction for all parameters measured for 'Brown Snout' specialty cider apple comparing hand harvest with machine harvest using an over-the-row small fruit harvester (model OR0012; Littau Harvester, Lyndon, WA) in 2011 and 2012 at Washington State University Northwestern Washington Research and Extension Center at Mount Vernon.

\begin{tabular}{llcc}
\hline & \multicolumn{3}{c}{ Pvalues } \\
\cline { 2 - 4 } Parameters measured & \multicolumn{1}{c}{ Yr } & Rootstock & Yr $\times$ Rootstock \\
\hline Total labor hours per acre & 0.004 & 0.08 & 0.64 \\
Cost per acre in dollars & 0.07 & 0.44 & 0.48 \\
Harvest weight per acre in pounds ${ }^{\mathrm{z}}$ & 0.0002 & 0.06 & 0.81 \\
Postharvest hand clean-up per acre in pounds & 0.26 & 0.58 & 0.79 \\
Total harvest weight per acre in pounds & 0.0002 & 0.06 & 0.9 \\
Percent harvest efficiency & 0.17 & 0.33 & 0.96 \\
Spurs damaged per tree & 0.001 & 0.08 & 0.19 \\
Limbs damaged per tree & 0.21 & 0.07 & 0.72 \\
Percent fruit damaged by cuts & 0.39 & 0.47 & 0.47 \\
Percent fruit cut in half & 0.62 & 1 & 0.62
\end{tabular}

${ }^{z}$ Hand harvest compared with machine pick.

${ }^{y}$ Hand harvest compared with machine pick + clean-up weight (fruit left on trees and fruit knocked to the ground during harvest).

Table 2. Mean fruit weight of harvest, clean-up (fruit left on trees and fruit knocked to the ground during harvest), and the total of harvest plus clean-up for hand harvest and machine harvest using an over-the-row small fruit machine harvester (model OR0012; Littau Harvester, Lyndon, WA) of 'Brown Snout' specialty cider apple in 2011 and 2012 at Washington State University Northwestern Washington Research and Extension Center at Mount Vernon.

\begin{tabular}{|c|c|c|c|c|c|c|}
\hline \multirow{3}{*}{$\begin{array}{l}\text { Harvest } \\
\text { method }\end{array}$} & \multicolumn{6}{|c|}{ Mean fruit wt (lb/acre $)^{\mathrm{z}}$} \\
\hline & \multicolumn{2}{|c|}{ Harvest } & \multicolumn{2}{|c|}{ Clean-up ${ }^{y}$} & \multicolumn{2}{|c|}{ Total harvest } \\
\hline & 2011 & 2012 & 2011 & 2012 & 2011 & 2012 \\
\hline $\operatorname{Hand}^{\mathrm{x}}$ & 8,159 & 1,932 & $0 \mathrm{a}^{\mathrm{w}}$ & 0 & 8,159 & 2,159 \\
\hline Machine & 5,576 & 1,546 & $8,485 \mathrm{~b}$ & 303 & 7,273 & 1,841 \\
\hline$P$ value ${ }^{v}$ & 0.11 & 0.53 & 0.007 & 0.06 & 0.59 & 0.77 \\
\hline
\end{tabular}

${ }^{\mathrm{z}} \mathrm{l} \mathrm{lb} /$ acre $=1.1209 \mathrm{~kg} \cdot \mathrm{ha}^{-1}$

yClean-up fruit weight included fruit left on trees and fruit knocked to the ground during harvest.

${ }^{x}$ Hand harvest included groundfalls.

${ }^{\text {w}}$ Means within a column followed by a different letter are significantly different $(P \leq 0.05)$ as determined by TukeyKramer honest significant difference test.

'Significance of treatment effects were analyzed using JMP (version 8.0.1 for Windows; SAS Institute, Cary, NC) with Oneway analysis of variance. 
was eight times greater than for machine harvest in 2011 and was two times greater in 2012 (Table 3). Hand-harvest labor-hours were three times greater in 2011 than in 2012 due to heavier fruit set and higher yields in 2011 . The number of hours for machine harvest was similar for both years as the same number of people (three) was required to operate the harvester regardless of crop load, and machine speed through the orchard did not vary greatly year to year. On average for the 2 years, hand harvest required 23 labor-hours per acre, while machine harvest required 5 labor-hours per acre. Generally, the 2-year average cost for harvest labor was four times greater for hand harvest $(\$ 417 /$ acre) than for machine harvest ( $\$ 93 /$ acre).

Tree HeAlTh, AND FRUIT AND JUICE QUALITY CHARACTERISTICS. Damage to limbs and spurs was relatively low for both harvest methods and did not differ significantly because of harvest method (Table 4). On average for the 2 years of this study, four spurs per tree were broken off and 0.5 limbs per tree were snapped because of hand harvest, while eight spurs and 0.8 limbs were damaged per tree because of machine harvest. All fruit (100\%) were bruised by both hand and machine harvest both years (data not shown). No fruit were sliced or cut in half with hand harvest either year, while on average over both years, $10 \%$ of fruit were sliced and $4 \%$ of fruit were cut in half inadvertently with machine harvest.

There were no significant differences due to harvest method for SSC, $\mathrm{pH}$, specific gravity, titratable acidity, or total tannin of fruit pressed immediately after harvest or after 2 to 4 weeks storage (Table 5 ). When fruit was pressed after storage ( 3 weeks in 2011,2 and 4 weeks in 2012), SSC and specific gravity of juice increased as compared with juice pressed immediately after harvest both years (Table 6). In 2011, SSC of juice increased $11 \%$ while specific gravity increased $1 \%$ when fruit was stored for 3 weeks, and in 2012, SSC of juice increased $12 \%$ and $18 \%$ while specific gravity increased $1 \%$ and $2 \%$ when fruit was stored for 2 and 4 weeks,

Table 3. Mean labor time and labor cost for hand harvest and machine harvest using an over-the-row small fruit machine harvester (model OR0012; Littau Harvester, Lyndon, WA) of 'Brown Snout' specialty cider apple in 2011 and 2012 at Washington State University Northwestern Washington Research and Extension Center at Mount Vernon.

\begin{tabular}{lccccc}
\hline \multirow{2}{*}{$\begin{array}{l}\text { Harvest } \\
\text { method }\end{array}$} & \multicolumn{2}{c}{ Mean labor time $(\mathbf{h} / \text { acre })^{\mathrm{z}}$} & & \multicolumn{2}{c}{ Mean labor cost $(\mathbf{\$} / \text { acre })^{\mathrm{y}}$} \\
\cline { 2 - 3 } \cline { 5 - 6 } & $\mathbf{2 0 1 1}$ & $\mathbf{2 0 1 2}$ & & $\mathbf{2 0 1 1}$ & $\mathbf{2 0 1 2}$ \\
\hline Hand $^{\mathrm{x}}$ & $34.5 \mathrm{a}^{\mathrm{w}}$ & 11.8 & & $621 \mathrm{a}$ & 212 \\
Machine $^{\mathrm{v}}$ & $4.2 \mathrm{~b}$ & 5.4 & & $81 \mathrm{~b}$ & 104 \\
vvalue $^{\mathrm{u}}$ & 0.0005 & 0.16 & & 0.008 & 0.18 \\
\hline
\end{tabular}

${ }^{\mathrm{z}}$ Labor hours for total harvest (harvest plus clean-up); $\mathrm{l} \mathrm{h} /$ acre $=2.471 \mathrm{l} \mathrm{h} \cdot \mathrm{ha}^{-1}$

yAll workers who handled fruit for hand and machine harvest were considered to be paid the same wage $(\$ 18 / \mathrm{h}$ including applicable taxes and benefits), while the machine harvester driver was valued at $\$ 22 / \mathrm{h}$ (including applicable taxes and benefits); wages were calculated based on those paid by local growers for similar work; $\$ 1.00$ / acre $=\$ 2.4711 /$ ha .

${ }^{x}$ Hand harvest was done by unskilled agricultural workers and not experienced fruit pickers.

"Means within a column followed by a different letter are significantly different $(P \leq 0.05)$ as determined by TukeyKramer honest significant difference test.

"Machine harvest was done with an experienced driver and two unskilled agricultural workers.

"Significance of treatment effects were analyzed using JMP (version 8.0.1 for Windows; SAS Institute, Cary, NC) with Oneway analysis of variance. respectively. For fruit that were stored, $\mathrm{pH}$ of juice tended to decline both years $(0.01 \mathrm{pH}$ units in 2011, 0.06-0.12 pH units in 2012); however, this difference was significant only in 2012. Changes in juice sugar content and $\mathrm{pH}$ with storage followed expected trends, as starch breaks down into sugars, sugars become more concentrated because of dehydration, and fruit acidity increases because of respiration during storage (Lea, 2008; Pollard, 1953; Trowbridge, 1917).

\section{Discussion}

On average with the over-therow small fruit harvester, $70 \%$ of fruit was harvested with the machine, $17 \%$ of fruit was retrieved from the trees or ground, and 13\% of fruit was lost. Fruit was lost when it fell onto the catch plate and bounced into the alley or under the harvester tires. To reduce the number of groundfalls and lost fruit, netting could be added to the front and back of the harvester to prevent fruit from bouncing out after it drops onto the catchplate. The amount of fruit harvested with the over-the-row harvester increased in 2012 (84\% of total machine harvest yield) as compared with 2011 (77\% of total machine harvest yield) because of changes in the tree training system, specifically, loosening the attachment of tree limbs to the trellis wires so that the harvester shaker bars could more readily shake the fruit off the trees, thereby reducing the number of fruit left on the tree. Use of ethephon to manage harvest timing and/or promote fruit abscission and a more uniform harvest might also be worth future study (Meland and Kaiser, 2011).

Overall yield of 'Brown Snout' specialty cider apple was reduced in this study because of initial orchard

Table 4. Damage to tree spurs and limbs per tree, and fruit damage (percent sliced and percent cut in half) due to hand harvest and machine harvest using an over-the-row small fruit machine harvester (model OR0012; Littau Harvester, Lyndon, WA) of 'Brown Snout' specialty cider apple in 2011 and 2012 at Washington State University Northwestern Washington Research and Extension Center at Mount Vernon.

\begin{tabular}{|c|c|c|c|c|c|c|c|c|}
\hline \multirow{2}{*}{$\begin{array}{l}\text { Harvest } \\
\text { method }\end{array}$} & \multicolumn{2}{|c|}{ Spurs damaged (no./tree) } & \multicolumn{2}{|c|}{ Limbs damaged (no./tree) } & \multicolumn{2}{|c|}{ Fruit sliced (\%) ${ }^{\mathrm{z}}$} & \multicolumn{2}{|c|}{ Fruit halves $(\%)^{\mathrm{z}}$} \\
\hline & 2011 & 2012 & 2011 & 2012 & 2011 & 2012 & 2011 & 2012 \\
\hline Hand & 1.1 & 7.0 & 0.1 & 0.9 & $0 \mathrm{~b}^{\mathrm{x}}$ & $0 \mathrm{~b}$ & $0 \mathrm{~b}$ & $0 \mathrm{~b}$ \\
\hline$P$ value $^{\mathrm{v}}$ & 0.46 & 0.1 & 0.25 & 0.9 & 0.006 & 0.004 & 0.02 & 0.002 \\
\hline
\end{tabular}

${ }^{\mathrm{z}}$ Mean for 100 fruit.

${ }^{y}$ Means within a column followed by a different letter are significantly different $(P \leq 0.05)$ as determined by Tukey-Kramer honest significant difference test.

${ }^{x}$ Significance of treatment effects were analyzed using JMP (version 8.0.1 for Windows; SAS Institute, Cary, NC) with Oneway analysis of variance. 
Table 5. Juice quality characteristics [soluble solids concentration (SSC), pH, specific gravity, titratable acidity, and percent total tannin] of 'Brown Snout' specialty cider apple due to havest method (hand harvest and machine harvest using an overthe-row small fruit machine harvester; model OR0012; Littau Harvester, Lyndon, WA) and year (2011 and 2012 ) at Washington State University Northwestern Washington Research and Extension Center at Mount Vernon.

\begin{tabular}{|c|c|c|c|c|c|}
\hline Harvest method & SSC (\%) & $\mathrm{pH}$ & $\begin{array}{l}\text { Specific gravity } \\
\text { (ratio) }\end{array}$ & $\begin{array}{c}\text { Titratable acidity [malic acid } \\
\left.\text { equivalents }\left(\mathrm{g} \cdot \mathrm{L}^{-1}\right)\right]^{\mathrm{z}}\end{array}$ & $\begin{array}{c}\text { Total tannin } \\
(\%)\end{array}$ \\
\hline Hand & 11.88 & 3.85 & 1.05 & 2.91 & 0.19 \\
\hline Machine & 12.19 & 3.88 & 1.05 & 3.20 & 0.19 \\
\hline$P$ value & 0.31 & 0.49 & 0.45 & 0.15 & 0.78 \\
\hline \multicolumn{6}{|l|}{ Year } \\
\hline 2011 & $10.86 \mathrm{~b}^{\mathrm{y}}$ & 3.82 & $1.04 \mathrm{~b}$ & $2.22 \mathrm{~b}$ & $0.15 \mathrm{~b}$ \\
\hline
\end{tabular}

${ }^{\mathrm{z}} \mathrm{l} \mathrm{g} \cdot \mathrm{L}^{-1}=1000 \mathrm{ppm}$.

${ }^{y}$ Means within a column followed by a different letter are significantly different $(P \leq 0.05)$ as determined by Tukey-Kramer honest significant difference test.

${ }^{\mathrm{x}}$ Significance of treatment effects were analyzed using JMP (version 8.0.1 for Windows; SAS Institute, Cary, NC) with Oneway analysis of variance.

Table 6. Quality characteristics [soluble solids concentration (SSC), pH, specific gravity, titratable acidity, and percent total tannin] of 'Brown Snout' specialty cider apple juice due to hand harvest and machine harvest using an over-the-row small fruit machine harvester (model OR0012; Littau Harvester, Lyndon, WA), measured immediately after harvest and stored (3 weeks in 2011, 2 and 4 weeks in 2012) in 2011 and 2012 at Washington State University Northwestern Washington Research and Extension Center at Mount Vernon.

\begin{tabular}{|c|c|c|c|c|c|}
\hline Press time & SSC (\%) & $\mathrm{pH}$ & $\begin{array}{l}\text { Specific gravity } \\
\text { (ratio) }\end{array}$ & $\begin{array}{c}\text { Titratable acidity [malic acid } \\
\left.\text { equivalents }\left(\mathrm{g} \cdot \mathrm{L}^{-1}\right)\right]^{\mathrm{z}}\end{array}$ & $\begin{array}{c}\text { Total tannin } \\
(\%)\end{array}$ \\
\hline \multicolumn{6}{|l|}{2011} \\
\hline 3 weeks & $12.05 \mathrm{a}$ & 3.81 & $1.05 \mathrm{a}$ & 2.34 & 0.49 \\
\hline$P$ value $^{\mathrm{x}}$ & 0.0002 & 0.63 & 0.0001 & 0.18 & 0.21 \\
\hline \multicolumn{6}{|l|}{2012} \\
\hline 4 weeks & $15.51 \mathrm{a}$ & $3.85 \mathrm{ab}$ & $1.07 \mathrm{a}$ & $4.56 \mathrm{a}$ & 0.23 \\
\hline$P$ value ${ }^{\mathrm{x}}$ & 0.0003 & 0.07 & $<0.0001$ & 0.09 & 0.27 \\
\hline
\end{tabular}

${ }^{\mathrm{z}} \mathrm{l} \mathrm{g} \cdot \mathrm{L}^{-1}=1000 \mathrm{ppm}$.

${ }^{y}$ Means within a column followed by a different letter are significantly different $(P \leq 0.05)$ as determined by Tukey-Kramer honest significant difference test.

${ }^{x}$ Significance of treatment effects were analyzed using JMP (version 8.0.1 for Windows; SAS Institute, Cary, NC) with Oneway analysis of variance.

management practices that were thought to be necessary to accommodate the over-the-row small fruit machine harvester. That is, rows were spaced $16 \mathrm{ft}$ apart and as a result, orchard tree density in this study (680 trees/acre) was 38\% lower than the recommended density for a similar training style (1100 trees/acre). For a similar sized over-the-row machine harvester, $10 \mathrm{ft}$ spacing between rows would be adequate. Although there is limited information regarding yield of specialty cider apples in the United States, Proulx and Nichols (1997) estimate that one dwarf cider apple tree (unspecified variety) will produce $\approx 45 \mathrm{lb}$ of fruit. In this study, the average maximum yield was $12 \mathrm{lb}$ of fruit per tree. The narrow canopy used in this study was likely one of the greatest factors limiting yield per tree, and a wider crop canopy such as used in a fruiting wall system would likely increase fruiting wood and subsequent yield. Tree height must be low enough to allow the machine harvester to pass over the row; $6.5 \mathrm{ft}$ was the height used in this study and is the maximum tree height for the machine harvester used in this study. An over-the-row machine harvester for olive (Olea europaea) has a $10 \mathrm{ft}$ over-the-row clearance and may be better suited to optimize apple yield.

Yield in both hand- and machineharvest plots was almost four times greater in 2011 than in 2012 . Although 'Brown Snout' is not an alternate bearing (biennial) variety, crop load management may not have been adequate to ensure consistent fruit load each year and likely affected year-to-year yield variation (Copas, 2001 ). The most significant cause of yield decline in the orchard in this study was due to an overall decline in tree health and orchard stand caused by apple anthracnose (Neofabraea malicorticis). Incidence of apple anthracnose did not appear greater in plots that were mechanically harvested, and spread does not appear to be enhanced by wounding (Gariepy et al., 2005). Although spur and limb damage were generally low due to machine harvest, they were almost twice as great as compared with hand harvest. Although this amount of tree damage may not directly impact yield, open wounds may be sites for infection of important diseases such as fire blight (Erwina amylovora), leading to significant effects on long term orchard health and yield (Kon et al., 2013).

In this study, harvest was done by general orchard workers and not by experienced fruit pickers. The region of Washington where this study was conducted does not have any large scale commercial apple production and there are no experienced apple harvest crews in the area. The number of labor hours for hand harvest with an experienced apple picking crew would likely be less than the number measured in this study, 
whereas the number of labor-hours for machine harvest would likely be similar. For machine harvest, apart from the driver, an experienced labor crew is not necessary, as the work does not require skill and training. Three workers are needed for the over-the-row small fruit harvester used in this study regardless of fruit load, and the speed of the machine harvester does not vary in the orchard because of crop load. Thus, labor cost savings in areas with experienced picking crews would likely not be as large as found in this study.

Another consideration for harvest is impact on fruit quality characteristics. In this study, hand harvest by unskilled agricultural workers resulted in all fruit being bruised. For machine harvest, all fruit were bruised and some fruit were also inadvertently sliced and cut by the harvester. In this study, cut and sliced fruit were not discarded after harvest, they remained in the stored boxes as this is likely how growers and cider makers would manage their fruit after harvest. When fruit was pressed immediately after harvest or when fruit were held in cold storage for up to 4 weeks, fruit remained of high quality. However, in commercial cider production where fruit is generally stored outside or in open barns for up to 1 month before pressing, cut and sliced fruit are more prone to rot, which causes off-flavors in the pressed juice (Lea, 2008; Trowbridge, 1917). Future studies should include an assessment of fruit rot and microbial growth in storage and an assay for off-flavors because of cut and sliced fruit. Storing cider fruit before pressing is referred to as "sweating" and is a common practice as it leads to increased sugar concentration through water evaporation from the fruit and hydrolysis of remaining starch in the fruit (Merwin et al., 2008; Trowbridge, 1917). Increased sugar concentration was observed in stored fruit in this study, similar to observations of Trowbridge (1917) and Williams (1975). Also observed in this study was a decline in juice $\mathrm{pH}$ of stored fruit, similar to observations of Pollard (1953).

A final consideration for the use of small fruit machine harvesters for cider apple harvest is the availability and cost of equipment. In Washington, the last raspberry harvest is in early September and cider apple harvest begins in late September; thus, use of small fruit machine harvest equipment would not conflict for the two crops. Although the results from this study are promising in regards to potential suitability of a small fruit over-the-row machine harvester for cider apples, some equipment modification may be needed to optimize cider apple harvest. First, small fruit harvest cups are too small for most cider apple varieties, and a belt with larger cups would be preferred. Second, the over-the-row harvester used in this study off-loaded fruit at the top of the machine into bushel boxes that were then stacked on the top platform. The platform was lowered to the ground at the end of the row and fruit were emptied into an orchard bin, which was both time and labor consuming. An over-therow harvester with side off-loading would be more efficient. And third, the maximum clearance for an overthe-row small fruit harvester is $6.5 \mathrm{ft}$, thus apple tree training and architecture must be considered to optimize fruit yield in this production system. The cost of an over-the-row small fruit harvester varies depending on manufacturer, year, model, wearand-tear (if used or refurbished), and location. In general, cost ranges from $\$ 70,000$ for used, refurbished models in good working order to $\$ 225,000$ for a new custom-built model. More information is needed to determine the costs of machine harvest to more completely compare the feasibility of over-the-row harvest to hand picking. To help address this need for additional information, a new study is underway at Washington State University to ascertain the cost of leasing equipment and the cost of custom harvest.

\section{Literature cited}

Alwood, W.B. 1903. A study of cider making. U.S. Dept. Agr., Bur. Chem. Bul. No. 71 .

Barker, B.T.P. 1903. Classification of cider apples. Natl. Fruit Cider Inst., Long Ashton Res. Sta., Bristol, UK.

Barker, B.T.P. 1911. Cider-making. J. Royal Hort. Soc. 36:570-573.

Barker, B.T.P. and L.F. Burroughs. 1953. Cider apple varieties then and now: A survey of vintage-quality trials, p. 45-55. In:
T. Wallace and R.W. Marsh (eds.). Science and fruit. Univ. Bristol, Bristol, UK.

Blanpied, G.D. and K.J. Silsby. 1992. Predicting harvest date windows for apples. Cornell Info. Bul. 221.

Brown, D. 2014. Washington cider market. 10 Apr. 2014. <https://cydermarket. com/Washington.htmls.

Buell, J.S. 1869. Cider makers' manual. Haas and Kelley, Buffalo, NY.

Burroughs, L.F. and G.C. Whiting. 1960. Annu. Rpt. Long Ashton Res. Sta., Bristol, UK.

Chu, C.L.G. and K.R. Wilson. 2000. Evaluating maturity of 'McIntosh' and 'Red Delicious' apples. Ontario Ministry Agr. Food Rural Affairs, Publ. Order No. 00-025. 22 July 2014. <http://www. omafra.gov.on.ca/english/crops/facts/ 00-025.htm>.

Copas, L. 2001. A Somerset pomona: The cider apples of Somerset. Dovecote Press, Wimborne, Dorset, UK.

Fallahi, E. 2012. Influence of rootstock and irrigation methods on water use, mineral nutrition, growth, fruit yield, and quality in 'Gala' apple. HortTechnology 22:731-737.

Fitzgerald, J., A. Berrie, C. Jay, L. Copas, J. Worle, G. Arnold, and J. Thatcher. 2013. Developing cider orchards for modern cider production. Asp. Appl. Biol. 111:1-3.

Funt, R.C., T.E. Wall, and J.C. Scheerens. 1998. Yield, berry quality, and economics of mechanical berry harvest in Ohio. Ohio State Univ. Res. Circ. 299-99. 19 Dec. 2013. <http://ohioline.osu.edu/rc299/ rc299_8.html>.

Galinato, S.P., R.K. Gallardo, and C.A. Miles. 2014. Cost estimation of establishing a cider apple orchard in western Washington. Washington State Univ. Ext. Publ. FS141E.

Gallander, J., L. Briner, J. Stetson, J.-W. Liu, L. Kreilow, K. Walker, R. Romberger, C. Stamp, and R. Reisen. 1991. Manual for wine analysis and laboratory techniques. Ohio State Univ., Ohio Agr. Res. Dev. Ctr., Wooster.

Gariepy, T.D., J.E. Rahe, C.A. Lévesque, R.A. Spotts, D.L. Sugar, and J.L. Henriquez. 2005. Neofabraea species associated with bull's eye rot and cankers of apple and pear in the Pacific Northwest. Can. J. Plant Pathol. 27:118-124.

Khanizadeh, S., Y. Groleau, I. Ali, D. Guarino, and R. Dumois. 2000. New hardy apple scab resistant selections for cider and juice production. Acta Hort. 538:697-702. 
Kon, T.M., J.R. Schupp, H.E. Winzeler, and R.P. Marini. 2013. Influence of mechanical string thinning treatments on vegetative and reproductive tissues, fruit set, yield, and fruit quality of 'Gala' apple. HortScience 48:40-46.

Lau, O.L. 1988. Harvest indices, dessert quality, and storability of 'Jonagold' apples in air and controlled atmosphere storage. J. Amer. Soc. Hort. Sci. 113:564-569.

Lea, A. 2008. Craft cider making. Good Life Press, Preston, UK.

Lehnert, R. 2010. High density apple systems cost more. 4 Feb. 2014. <http://www.goodfruit.com/high-densityapple-systems-cost-more $/>$.

Lowenthal, J. 1877. Uber die bestimmung des gerbstoffs. Z. Anal. Chem. 16:33-48.

Marshall, D.W. and P.K. Andrews. 1994. Trends in Washington state's apple industry. HortTechnology 4:6-15.

Meland, M. and C. Kaiser. 2011. Ethephon as a blossom and fruitlet thinner affects crop load, fruit weight, fruit quality, and return bloom of 'Summerred' apple (Malus $\times$ domestica) Borkh. HortScience 46:432-438.

Merwin, I.A., S. Valois, and O. PadillaZakour. 2008. Cider apples and cidermaking techniques in Europe and North America. Hort. Rev. 34:365-414.

Morton, A. 2013. U.S. cider still taking bite out of beer - C\&C Group. 30 Oct. 2013. <http://www.just-drinks.com/ analysis/just-on-call-us-cider-still-takingbite-out-of-beer-cc-group_idl11932.aspx>.

Moulton, G., C. Miles, J. King, and A. Zimmerman. 2010. Hard cider production and orchard management. Washington State Univ. Ext. Pub. PNW621.

National Association of Cider Makers. 2010. NACM statistics. 23 Dec. 2013. <http://cideruk.com/files/publications/ NACM_Charts_for_Website_-_6_$21 \mathrm{Dec} 2010 . \mathrm{pdf}>$.

Northwest Cider Association. 2014. Northwest Cider Association members. 10 Apr. 2014. <http://www.nwcider. com $/$ member-cideries $/>$.

Pollard, A. 1953. Factors affecting the quality of cider, p. 56-67. In: T. Wallace and R.W. Marsh (eds.). Science and fruit. Univ. Bristol, Bristol, UK.

Proulx, A. and L. Nichols. 1997. Cider: Making, using, and enjoying sweet and hard cider. 3rd ed. Storey Publ., North Adams, MA.

Schotzko, R.T. and D. Granatstein. 2005. A brief look at the Washington apple industry: Past and present. Washington State Univ. School Econ. Sci. SES-04-05. 19 Dec. 2013. <http://www.agribusinessmgmt.wsu.edu/agbusresearch/docs/ SES04-05_BRIEF_LOOK_WAFTA.pdf>.

Trowbridge, J.M. 1917. The cider makers' hand book-A complete guide for making and keeping pure cider. Orange Judd, New York, NY.
U.S. Department of Agriculture. 2013. Web soil survey. 17 Sept. 2013. <http:// websoilsurvey.sc.egov.usda.gov/App/ HomePage.htm>.

U.S. Department of Agriculture. 2014. National agricultural census: Apples. 4 May 2014. <http://www.nass.usda. gov/Statistics_by_State/Washington/>.

U.S. Department of Treasury. 2001. Hard cider, semi-generic wine designations, and wholesale liquor dealers' signs. Federal Register 66, No. 227, Rules and Regulations, p. 58938-58944. 22 July 2014 . <http://www.ttb.gov/rrd/ td470.pdf>.

U.S. Department of Treasury. 2013. Implementation of public law 105-34, sections 908,910 and 1415 , related to hard cider, semi-generic wine designations, and wholesale liquor dealers' signs (97-2523). U.S. Dept. Treasury, Bur. Alcohol Tobacco Firearms, 27 CFR Parts 4, 19, 24, 194, 250 and 251. 9 May 2014. <http://www.ttb.gov/rrd/tdatf398.htm>.

Washington State University Extension. 2013. Apples in Washington state. 29 Oct. 2013. <http://county.wsu.edu/chelandouglas/agriculture/treefruit/Pages/ Apples_in_Washington_State.aspx $>$.

Watson, B. 1999. Cider hard and sweet: History, traditions, and making your own. Countryman Press, Woodstock, VT.

Williams, R.R. 1975. An introduction to modern cider apple production. Long Ashton Res. Sta., Bristol, UK. 